\title{
Preface
}

Thomas Jefferson wrote about half a dozen letters a day, communicating widely. That was two hundred years ago, yet it is still an inspiration today. Now modern options exist as alternatives to letter writing —emails, texting, and more- and there are those who lament that the gentle art of letter writing has been sidelined. There are truths in such laments, but I find myself in an office with thousands of letters written by a wide variety of letter writers. My attention was initially focused on file drawers full of hundreds of letters for the most part alphabetized, simply because I needed to sort overloaded office files. In rereading some of the letters, however, I realized there were stories there. Such correspondence, received over half a century since coming to Berkeley in 1960, was making connections between the academy, sometimes described as an Ivory Tower, and the public. Indeed, the university is now seen as inextricably linked to the world outside the university.

In anthropology there are few published books of letters from well-known academics. Margaret Mead's letters, both private and personal, were selected for publication after her death by editors who found the materials in the Library of Congress archives-To Cherish the Life of the World: Selected Letters of Margaret Mead. ${ }^{1}$ The correspondence between Edward Sapir and A. L. Kroeber covered letters written between 1905 and 1925-a total of 363 letters, many handwritten, some in pencil saved by Kroeber, thrown out by Sapir. ${ }^{2}$ Niko Besnier wrote Literacy, Emotion, and Authority about the transformation from a nonliterate to a literate society. ${ }^{3}$ In addition, there is The Story of a Marriage: The Letters of Bronislaw Malinowski and Elsie Masson-letters between Malinowski and his wife, a chronicle of their marriage including letters from the field. ${ }^{4}$ Mark Goodale's Letters to the Contrary: A Curated History of the UNESCO Human Rights Survey deals with a complex history of the human rights movement. ${ }^{5}$

The letters selected for this volume give a glimpse of academic life mostly unseen by academics and by the public at large. They were sent by academic colleagues (to be expected, perhaps), but they were also sent from lawyers, politicians, citizens, people in prisons or on death row, Peace Corps workers, members of the military, scientists, and more. Letters not included here were the massive correspondences between my students and me, letters of promotion, of praise, invitations, and thank-yous. Personal letters and family letters have also been left out. But what does remain are personal stories of half a century of our country's 
history from below and above, both from inside and outside the academyconversations, if you will, between a world full of folks and the anthropologist.

Most collections of letters are letters sent, not letters sent and received. There are probably good reasons, especially those related to legal requirements for permission to publish. For this collection, we sent physical mail to each of the selected authors. This required tenacious detective work, patience, persistence, and of course time.

Interestingly, among hundreds selected we received one negative response from someone who heard me speak on the $\mathrm{BBC}$ and strongly disagreed with what I had to say. A second negative was from someone I knew personally who simply did not want her letter published but gave no explicit reason.

An interesting set of observations resulted from the permissions process. Older people enjoyed being reminded of what they were like in their younger days, some children remarked that their parents would be pleased to be remembered, while a few other children felt that bad behavior should preclude their parents from receiving further public attention. Some were surprised that I did not take offense at the criticism received in certain letters. Still other family members of well-known academics had not seen the materials sent to me, and one author found it most useful in the biography he was writing about a well-known sociologist. Some wrote additional letters catching me up on what they were presently doing since sending their original letter. And many said that they would like to read such a book!

The letters that follow appear in their original form, with only minor edits made. Spelling corrections that did not alter meaning were made without brackets. Punctuation was standardized in accordance with the Chicago Manual of Style. In a small number of instances, bracketed words were inserted to address any outright typos or dropped words or spell out acronyms.

This collection makes available correspondences that are usually unknown because they are mainly private, in contrast to letters written to the editor of a media outlet. As one of my students noted, "The only letters my generation gets are bank statements, credit card bills, or letters from colleges.” Hopefully the letters in this volume will inspire both young and old to experience the privacy and freedom such communication affords, whether they be interested in history, law, science, modes of censorship, the evolution of social action, or just plain curious as to what happens when pen is put to paper, or when pen is put down to ponder. 


\section{LAURA NADER}


